\title{
Is proximity to oil refinery a big factor in explaining
}

\section{differences in gas prices?}

\author{
James O. Bukenya ${ }^{1,2}$, Fitzroy White ${ }^{1,3}$ \\ (1. Department of Agribusiness, Alabama A\&M University, Normal 35762, USA; \\ 2. Center for Urban and Rural Research (CURR), Alabama A\&M University, Normal 35762, USA; \\ 3. Faculty of Science and Agriculture, The University of the West Indies, St. Augustine, Trinidad)
}

\begin{abstract}
According to the Energy Information Administration, average retail gasoline prices tend to typically be higher in certain states than in others. Aside from taxes, the factors shown to contribute to regional and even local differences in gasoline prices include proximity of supply, supply disruptions, competition in the local market and environmental programs. Of interest in this paper is proximity of supply. It has been hypothesized that areas farthest from the Gulf Coast (the source of nearly half of the gasoline produced in the United States and, thus, a major supplier to the rest of the country) tend to have higher prices. To test this hypothesis, the paper assembles state level monthly retail gasoline data for the period 1983 to 2007 for five states with oil refineries (Alabama, Georgia, Texas, Mississippi and Louisiana) and five states without refineries (Arkansas, Tennessee, North Carolina, South Carolina and Florida). The analysis employs dynamic correlation, regression, cointegration and vector autoregressive methods. Overall, the results show that retail gas prices in states with refineries and those without refineries tend to move in the same direction over time. The small differences observed over time may suggest that price shocks take a short time to be felt nationwide.
\end{abstract}

Key words: oil refinery; prices; time series analysis; trend analysis

\section{Introduction}

What can be termed the most far reaching macroeconomic variable in the world today is undoubtedly the effect of high crude oil prices (Mork, 1994; Pirog, 2005; Pirog, 2004; Rogoff, 2006; Stevens, 2004; Williams, 2008). As expected, high crude oil prices have led to a rapid rise in retail gasoline prices throughout the world, in general and in the United States in particular. Given the importance of gasoline for the United States economy, it is essential to understand the market for gasoline and the factors that influence the prices that consumers pay (GAO, 2007). At the national level, the literature points to factors such as the price of crude oil, increasing demand for gasoline, refinery capacity in the United States that has not expanded at the same pace as the demand for gasoline, a declining trend in gasoline inventories, and regulatory factors, such as national air quality standards - that have induced some states to switch to special gasoline blends (GAO, 2007) as the major

James O. Bukenya, associate professor, Department of Agribusiness, Alabama A\&M University, co-director, Center for Urban and Rural Research (CURR), Alabama A\&M University; research fields: economic policy, regional economics and development, labor markets, human capital, demographic change.

Fitzroy White, former undergraduate research assistant, Department of Agribusiness, Alabama A\&M University, graduate student, Faculty of Science and Agriculture, The University of the West Indies; research fields: commodity markets, production economics and time series analysis. 
determinant of gasoline prices.

There are additional factors at the regional or local levels (such as local taxes, proximity of supply or transportation cost, supply disruptions and competition in the local market) that contribute to regional and even local differences in gasoline prices. Of interest in this paper is proximity of supply and/or transportation cost. For instance, EIA data shows that areas farthest from the Gulf Coast (the source of nearly half of the gasoline produced in the United States and, thus, a major supplier to the rest of the country) tend to have higher prices (EIA, 2006). To test this hypothesis, the paper assembles state level monthly retail gasoline data for the period 1983 to 2007 for five states with oil refineries (Alabama, Georgia, Texas, Mississippi and Louisiana) and five states without refineries (Arkansas, Tennessee, North Carolina, South Carolina and Florida). Ideally, one would expect retail price of gasoline in states with oil refineries to be stable over time because of proximity to supply. This proximity issue would rule out the high transportation costs which would normally impact retail gasoline prices.

The analysis therefore proceeds to examine the relationships between prices in selected southern states with and without oil refineries. The rest of the paper is organized into four additional sections. Section 2 presents and discusses the trends in gasoline retail price trends followed by the methodological approach in section 3 . The discussion of the results is presented in section 4 followed by the conclusions in the last section.

\section{Data}

Monthly data for gasoline prices (in nominal U.S. dollar per barrel) were gathered from the U.S. Department of Energy's Energy Information Administration. All monthly price series are found on the Energy Information Administration's website under the Petroleum Prices section (EIA, 2008). The data represents ten southern US States (Alabama, Louisiana, Texas, Mississippi, Georgia, Florida, North and South Carolina, Arkansas and Tennessee). Table 1 presents the descriptive statistics and the characteristics of the respective series, while the evolutions of the series are presented in Fig. 1 and Fig. 2. Table 1 shows all price indices have asymmetric distribution as the skewness coefficients are different from zero. The kurtoses of all series are greater than zero indicating that the tails of their distribution are fatter than the normal distribution. The sample variance suggests that South Carolina gasoline prices are the most volatile among non-oil refinery states, and Alabama and Georgia prices are the most volatile among states with oil refineries.

Table 1 Descriptive statistics and characteristics of the price series

\begin{tabular}{|c|c|c|c|c|c|c|c|}
\hline & Min. & Max. & Mean & S.D. & Variance & Skewness & Kurtosis \\
\hline \multicolumn{8}{|c|}{$\begin{array}{l}\text { Group I: } \\
\text { States with refineries }\end{array}$} \\
\hline Alabama & 56.40 & 258.40 & 99.99 & 43.84 & $1,995.19$ & 2.08 & 6.66 \\
\hline Georgia & 50.90 & 259.20 & 98.10 & 45.69 & $2,166.40$ & 2.05 & 6.54 \\
\hline Louisiana & 52.80 & 258.40 & 98.98 & 44.78 & $2,081.35$ & 2.07 & 6.65 \\
\hline Mississippi & 56.80 & 258.20 & 100.63 & 44.14 & $2,022.13$ & 2.02 & 6.42 \\
\hline Texas & 51.50 & 258.60 & 98.25 & 44.55 & $2,056.59$ & 2.08 & 6.77 \\
\hline \multicolumn{8}{|c|}{$\begin{array}{l}\text { Group II: } \\
\text { States without refineries }\end{array}$} \\
\hline Tennessee & 51.60 & 256.50 & 97.79 & 44.64 & $2,067.40$ & 2.05 & 6.59 \\
\hline Arkansas & 50.00 & 259.50 & 96.75 & 44.32 & 2,039.82 & 2.05 & 6.66 \\
\hline Florida & 54.10 & 262.60 & 100.98 & 44.66 & $2,072.51$ & 2.03 & 6.47 \\
\hline N. Carolina & 52.20 & 254.60 & 97.84 & 44.28 & $2,034.28$ & 2.05 & 6.57 \\
\hline S. Carolina & 49.80 & 257.60 & 97.60 & 45.15 & $2,114.42$ & 2.02 & 6.46 \\
\hline
\end{tabular}


As noted, Fig. 1 and Fig. 2 display the evolution of the price series. More specifically, the figures show the annual spot price of gasoline in the respective states, measured in U.S. dollars. The series show the dynamic behavior of retail gasoline prices for both states with and with no oil refineries. Particularly, a downward trend is observed from the middle of 1983 to 1984 after which a short lived spike occurred followed by a drastic nose dive in 1986. Overall, there is prolonged instability in the series with ups and downs depict until 1999 when a sharp rise took place. This was the beginning of an era of erratic ups and downs leading to a prolonged rise observed in the past few years.

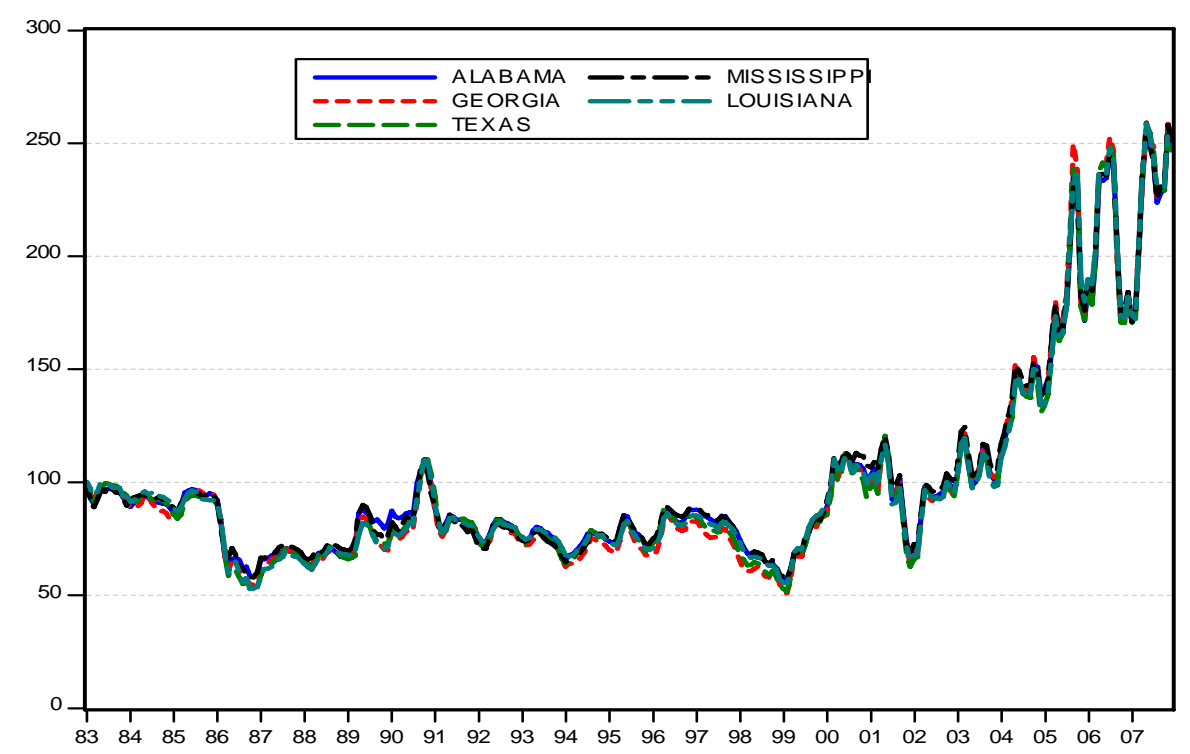

Fig. 1 Gasoline retail prices (Group I: States with refineries)

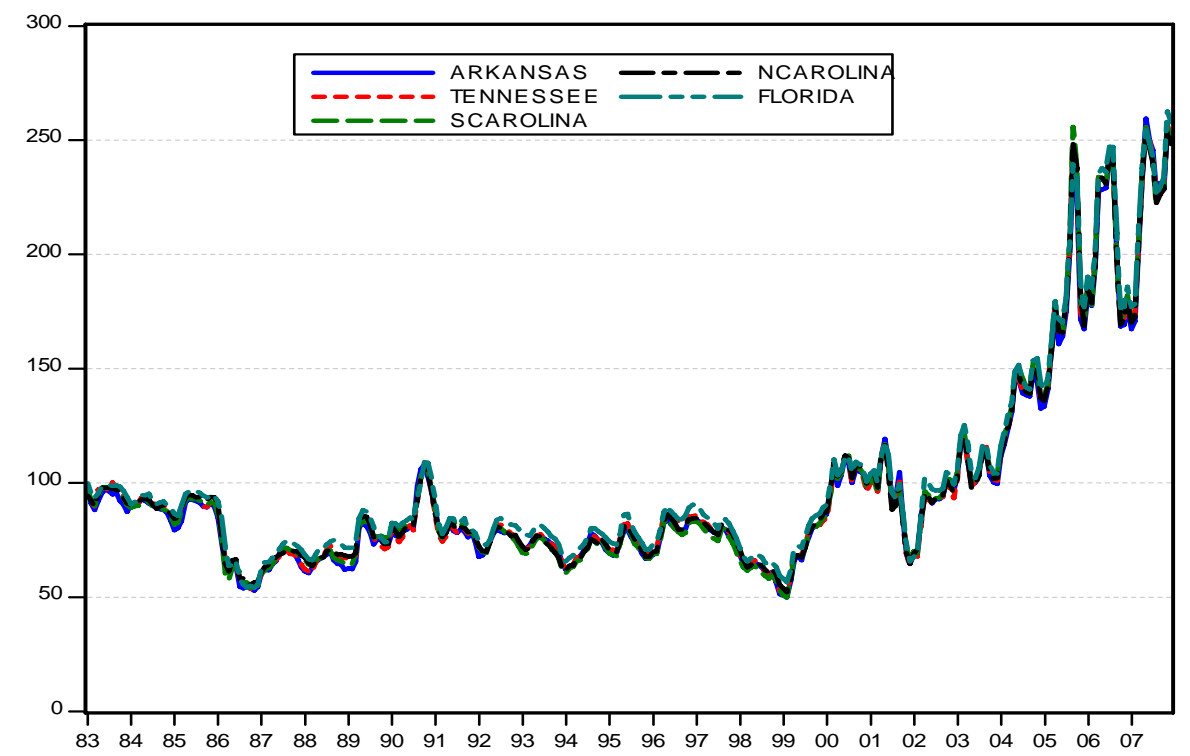

Fig. 2 Gasoline retail prices (Group II: States without refineries)

\section{Methodology}

Various economists have attempted to empirically analyze the behavior of oil prices using different 
econometric techniques. Earlier studies, such as Weiner (1991) adopt correlation analysis and switching regression technique to test whether the oil market is unified or regionalized while Gülen (1997) reexamines Weiner's hypothesis using cointegration analysis. Labys (2000) and Kyrtsou and Labys (2005) employ Chaotic tests of the relation between oil prices and inflation. Dibooglu and Aleisa (2004) investigate the sources of macroeconomic fluctuations in Saudi Arabia using Structural Vector Autoregression method. Most recently, Fattouh (2008) model crude oil price differentials as a two-regime threshold autoregressive process using Caner and Hansen's (2001) method. These studies provide insights in the best methods to analyze gasoline prices. In the present context, we employ two tests: (1) Dynamic correlation analysis to study the short-run responses; and (2) Cointegration analysis to study the equilibrium relationship between the different price series. A brief discussion on each of these techniques follows.

\subsection{Dynamic correlation analysis}

The computation of simple correlation coefficients within different sub-periods of a total sample period can be employed to study the dynamics of the linkages between variables separated by space (Weiner, 1991). However, since correlation analysis is static rather than dynamic, it is also important to examine cross-correlations with a lag structure between the variables of interest (Bukenya \& Labys, 2005). To accomplish this, simple correlation coefficients $\left(r_{i}^{2}\right)$ within different sub-periods of the total sample are calculated. Following Bukenya and Labys (2005), the estimated $r_{i}^{2}$ coefficients are then used to estimate the dynamic correlation indexes, $C_{i j}$ and $C_{i T}$ as:

$$
\begin{gathered}
C_{i j}=\frac{r_{12}^{2}+r_{13}^{2}+r_{14}^{2}+\ldots+r_{45}^{2}}{n_{c_{2}}} \\
C_{i T}=\frac{C_{i j}}{C_{11}}
\end{gathered}
$$

where $i=1,2, \ldots, 5 ; j=1 ; T=1,2, \ldots, 24$; and $C_{11}$ is the $C_{i j}$ for the first sub-period. Here, $i$ represent a state; $j$ represents a commodity (gasoline) and $T$ represents sub-periods in each case. In the above equations, a coefficient of $C$ equal to 1 would be interpreted as a perfect transmission of price shock, while a coefficient of 0 would represent a short-run invariance to changes in price elsewhere. Since the short-run effect is in principle unrestricted, a value of $C_{i T}$ greater than unity, for example, would suggest an over-reaction to changes in price in the current period.

\subsection{Cointegration analysis}

A growing body of empirical literature has used cointegration techniques in measuring equilibrium relationships between variables. Previous applications to commodity prices include Bukenya and Labys (2005), Asche, et al (1999), Gülen (1996), Bernard and Durlauf (1995), Alexander and Wyeth (1994), Zanias (1993) and Goodwin (1992). Since only non-stationary series can be subject to cointegration analysis, the first step is to confirm that the variables are nonstationary and integrated of the same order. To this end, several different tests are available. In the present context, the authors employ the Dickey-Fuller and Augmented Dickey-Fuller tests using the following regression:

$$
\Delta y_{t}=a+g y_{t-1}+\sum_{i=1}^{k} b_{i} \Delta y_{t-i}+e_{t}
$$

The lag length $k$ is chosen to generate a white noise error term $e_{t}$. To determine whether $y_{t}$ is nonstationary, the null hypothesis of nonstationarity is evaluated by testing whether $g=0$ against the alternative of stationarity $g<0$. Following stationarity tests, the authors proceed with cointegration tests using the Bernard and Darlauf (1995) method. Since this methodology has been extensively discussed in the literature, the authors only offer brief 
descriptions.

The Bernard and Durlauf (1995) approach defines long-run convergence between countries $i$ and $j$ if the long-term forecasts of the price variable for both countries are equal at a fixed time $t$ :

$$
\lim _{k \rightarrow \infty} E\left(p_{i, 1+k}-p_{j, t+k} \mid \xi_{t}\right)=0
$$

where $\xi_{t}$ stands for the information available at time $t$. This definition is satisfied if $p_{i, 1+k}-p_{j, t+k}$ is a mean zero stationary process. This implies that variables for countries $i$ and $j$ to converge, the two series must be cointegrated with cointegrating vector $[1,-1]$. In addition, if the variables are trend-stationary, then the definitions imply that the trends for each country must be the same. Recent empirical application of this approach to gasoline prices is Bentzen (2003) who estimates a cointegrating equation of the form:

$$
\Delta\left(p_{i, t}-\bar{p}_{t}\right)=\alpha+\beta_{t}+\mu\left(p_{i, t-1}\right)+\text { lags of } \Delta\left(p_{i, t}-\bar{p}_{t}\right)+\varepsilon_{t}
$$

Following Bentzen (2003), equation (5) is estimated where the test relies on a Dickey-Fuller type of test for a unit root in the difference of the (log) values of crude oil prices, with $t$ indicating a time trend. In the presence of a unit root, gasoline price in states with refineries and the group average price for states with no refineries will be driven by separate stochastic trend and, hence, diverge over time. On the other hand, the absence of a unit root in equation (5) implies that the intercept term and the deterministic trend parameter may be insignificant and thus indicate long-run convergence. Finally, when the deterministic trend parameter differs significantly from zero, a catching-up process is likely to take place assuming that the initial values of gasoline prices differ in levels (Bentzen, 2003).

\section{Estimated results}

\subsection{Dynamic correlation analysis}

The estimated dynamic correlation indexes $C_{i j}$ and $C_{i T}$ are reported in Table 2, with price series for states with oil refineries represented as Group I while price series for states with no oil refineries represented as Group II. Also, the graphical representations of the $C_{i T}$ indexes are depicted in Fig. 3. As noted earlier, a coefficient of 1 in Table 2 represents a perfect transmission of price shocks, while a coefficient of 0 represents a short-run invariance to changes in prices elsewhere. Since the short-run effect is in principle unrestricted, $C_{i T}$ greater than unity suggests an over-reaction to changes in prices in the current period. As shown in Fig. 3, the estimated $C_{i T}$ coefficients for all sub-periods are greater than unit, with the exception of January 1984 through December 1984 sub-period for Group I and January 1988 through December 1988 sub-period for Group II series, implying an over-reaction to changes in gasoline prices in the current period. Thus, the general conclusion here is that proximity to supply as measured by the presence of oil refineries in a state is not a big factor in explaining differences in gasoline prices across the southern U.S. in the short-run since the series exhibit similar trends.

\subsection{Cointegration analysis}

To perform the cointegration analysis of the retail gas price variables, unit root tests are first conducted using the Augmented Dickey-Fuller method, hereafter ADF (Dickey \& Fuller, 1979; Dickey \& Fuller, 1981). Whether or not to include the linear trend in conducting unit root tests is still contentious. For instance, McCoskey and Selden (1998) indicated that the ADF regressions should not include any linear trend, because the intercept itself already acts as a trend and power is lost in the case of a limited sample. To the contrary, Hansen and King (1996) argued that the time trend is evident and must be included to apply the ADF test in its general form. In this paper, unit root tests are performed using equations that incorporate a constant with and without a trend. The 
non-rejection of the null hypothesis for the unit root indicates that the series is characterized by a random walk representation (Dickey \& Fuller, 1979; Davidson \& MacKinnon, 1993).

Table 2 Dynamic correlation index

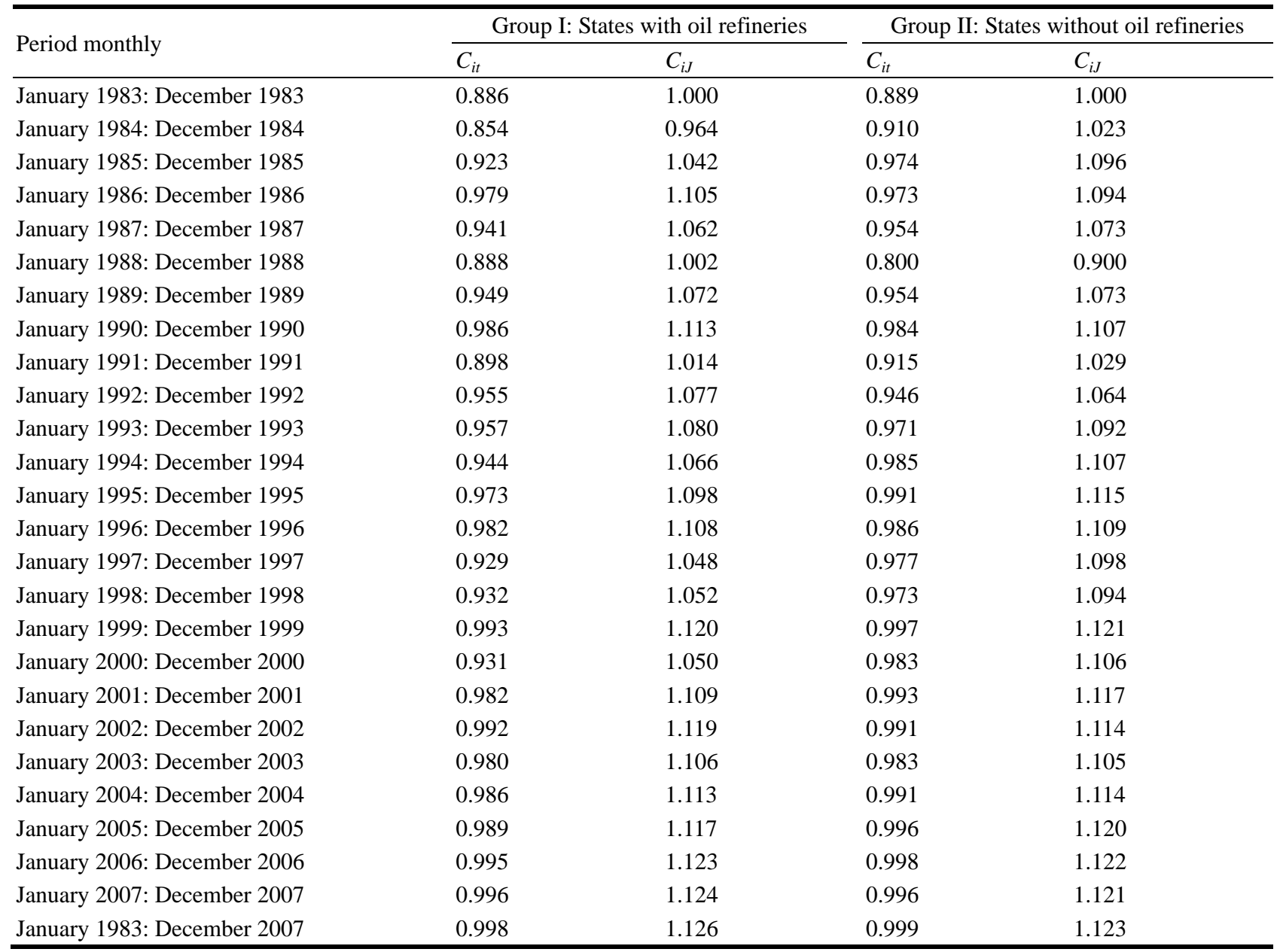

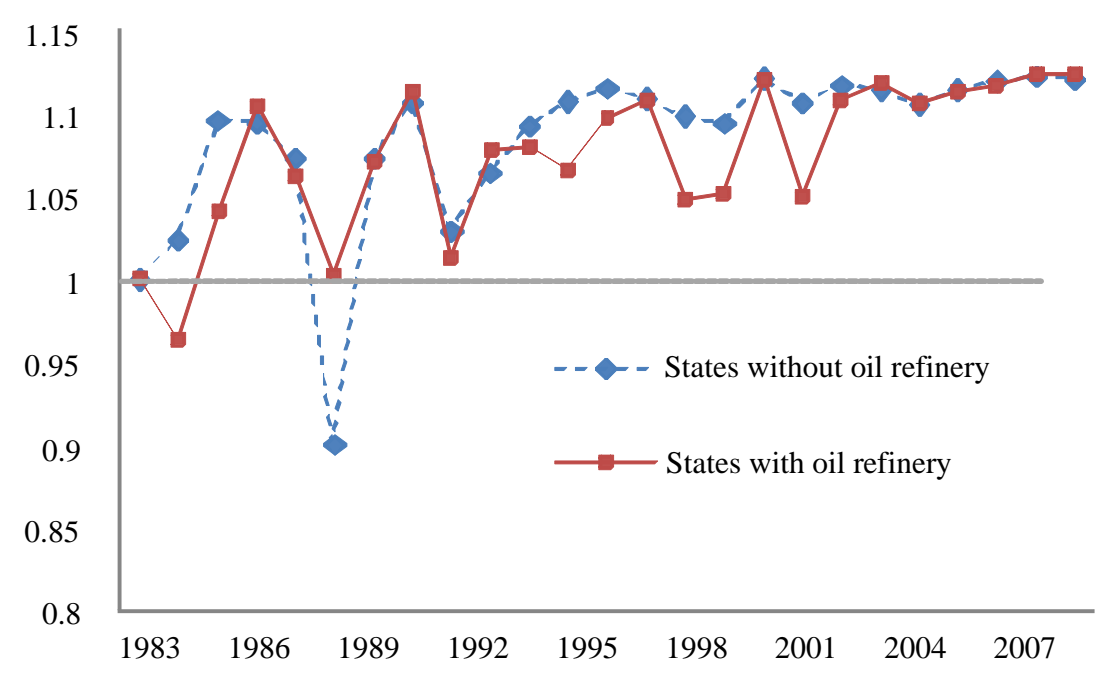

Fig. 3 Dynamic correlation index $\left(C_{i T}\right)$ 
The findings suggest that the null hypothesis of a random walk in the levels series, when a time trend is included, cannot be rejected in all series (see Table 3). Critical values at the 5 percent level of significance require t-statistics in excess of 3.54 in absolute value for rejection of the null hypothesis (Fuller, 1976, p. 373); here the estimated t-statistics are below 3.54 in absolute values. To the contrary, the null hypothesis of a random walk in the first differences is rejected for all series. That is, the ADF $t$-statistics on the first difference series with a trend for all commodities are all in excess of 5.0 in absolute value. These findings suggest that the first differences of all series are stationary.

Turning to the no time-trend specification, the results for the level series are consistent with the earlier findings for the time trend specification (see Table 3). Under the no time-trend specification, an approximate 5 percent critical value of -2.95 is used and the null hypothesis of a random walk in the levels series is not rejected since the test statistics are not greater than the critical values for all series. On the contrary, however, the null hypothesis of a random walk in the first difference series is rejected for all series. Similar to the trend specification, the first differences of each series under the no time-trend specification are stationary for all series.

Table 3 Augmented Dickey Fuller (ADF) test results

\begin{tabular}{|c|c|c|c|c|}
\hline \multirow[t]{2}{*}{ Series } & \multicolumn{2}{|c|}{ ADF (Trend) } & \multicolumn{2}{|c|}{ ADF (No trend) } \\
\hline & Levels & 1ST differences & Levels & 1ST differences \\
\hline \multicolumn{5}{|c|}{$\begin{array}{l}\text { Group I: } \\
\text { States with oil refineries }\end{array}$} \\
\hline Alabama & -1.01 & $-10.58 *$ & 1.21 & $-10.15^{* *}$ \\
\hline Georgia & -1.19 & $-10.83 *$ & 1.05 & $-10.40 * *$ \\
\hline Louisiana & -1.11 & $-10.61^{* *}$ & 1.10 & $-10.14^{* *}$ \\
\hline Mississippi & -1.10 & $-10.53^{* *}$ & 1.16 & $-10.08 * *$ \\
\hline Texas & -1.34 & $-10.57 * *$ & 0.93 & $-10.20 * *$ \\
\hline \multicolumn{5}{|c|}{$\begin{array}{l}\text { Group II: } \\
\text { States without oil refineries }\end{array}$} \\
\hline Arkansas & -1.26 & $-10.97 * *$ & 1.02 & $-10.52 * *$ \\
\hline Florida & -1.03 & $-10.83 * *$ & 1.21 & $-10.35^{* *}$ \\
\hline N. Carolina & -1.11 & $-10.67 * *$ & 1.12 & $-10.26^{* *}$ \\
\hline S. Carolina & -1.15 & $-10.81^{* *}$ & 1.11 & $-10.40 * *$ \\
\hline Tennessee & -1.09 & $-10.65^{* *}$ & 1.14 & $-10.22 * *$ \\
\hline
\end{tabular}

Note: $*(* *)$ denotes rejection of the hypothesis at $5 \%(1 \%)$ significance level.

On the basis of the above unit root tests, cointegration analysis is conducted to examine whether proximity to supply is a big factor in explaining the differences in gasoline prices across states. To answer this question, it is probably more appropriate to conduct cointegration test among the group average price for states with no refineries and individual states with oil refineries and vice versa. For that purpose, the authors use a procedure introduced by Benard and Durlauf (1995) and recently used by Bentzen (2003) which provides estimation of the relationship between the group average series for states with no refineries (Group II) and individual state series for states with oil refineries; and the group average series for states with refineries (Group I) and individual state series for states with no oil refineries. The results are reported in Table 4.

First, among Group I states, the unit root hypothesis is rejected in all states; and the intercept terms are not statistically different from zero, indicating that differences in retail gasoline price between states with oil refineries and those with no refineries will likely vanish over time as the time trend is most likely zero. Similarly, the unit root hypothesis is rejected among Group II states, implying the presence of a long-run relationship between Group I 
and Group II state price series. Thus, the general conclusion here is that proximity to supply as measured by the presence of oil refineries in a state is not a big factor in explaining differences in gasoline prices across the southern U.S. in the long-run.

Table 4 Test statistics for convergenge (catching up) hypothesis

\begin{tabular}{|c|c|c|c|c|c|}
\hline & ADF test & $\hat{\alpha}$ & $\hat{\beta}$ & $\mathrm{R}^{2}$ & D-W stat \\
\hline \multicolumn{6}{|c|}{$\begin{array}{l}\text { Group I: } \\
\text { States with oil refineries }\end{array}$} \\
\hline Alabama & $-9.080888 * *$ & $\begin{array}{l}0.017908 \\
0.073133\end{array}$ & $\begin{array}{l}0.097693 \\
0.058812\end{array}$ & 0.648776 & 1.973211 \\
\hline Georgia & $-10.50745^{* *}$ & $\begin{array}{l}0.256779 \\
0.056198\end{array}$ & $\begin{array}{l}0.095008 \\
0.059720\end{array}$ & 0.651101 & 1.981922 \\
\hline Louisiana & $-10.27300^{* *}$ & $\begin{array}{l}0.118625 \\
0.027891\end{array}$ & $\begin{array}{l}0.109912 \\
0.060073\end{array}$ & 0.725150 & 2.005072 \\
\hline Mississippi & $-10.67749 * *$ & $\begin{array}{l}0.165247 \\
0.071951\end{array}$ & $\begin{array}{l}0.093479 \\
0.058615\end{array}$ & 0.625969 & 1.993342 \\
\hline Texas & $-8.768068 * *$ & $\begin{array}{l}0.015806 \\
0.002807\end{array}$ & $\begin{array}{l}0.079783 \\
0.059708 \\
\end{array}$ & 0.475402 & 1.983310 \\
\hline $\begin{array}{l}\text { Group II: } \\
\text { States without oil r }\end{array}$ & & & & & \\
\hline North Carolina & $-10.37651^{* *}$ & $\begin{array}{l}0.099484 \\
0.040806\end{array}$ & $\begin{array}{l}0.100718 \\
0.058501\end{array}$ & 0.689089 & 1.984178 \\
\hline South Carolina & $-11.00411^{* *}$ & $\begin{array}{l}0.221352 \\
0.046445\end{array}$ & $\begin{array}{l}0.098327 \\
0.059337\end{array}$ & 0.650016 & 2.009287 \\
\hline Tennessee & $-10.72720^{* *}$ & $\begin{array}{l}0.166048 \\
0.005228\end{array}$ & $\begin{array}{l}0.100264 \\
0.057585\end{array}$ & 0.682889 & 1.985718 \\
\hline Florida & $-9.993391 * *$ & $\begin{array}{l}0.168978 \\
0.044475\end{array}$ & $\begin{array}{l}0.094929 \\
0.060655\end{array}$ & 0.589667 & 1.984927 \\
\hline Arkansas & $-11.92071^{* *}$ & $\begin{array}{l}0.314165 \\
0.125567\end{array}$ & $\begin{array}{l}0.094468 \\
0.058485\end{array}$ & 0.640269 & 2.017237 \\
\hline
\end{tabular}

Note: $(* *)$ denotes rejection of the hypothesis at $1 \%$ significance level.

\section{Conclusion}

If proximity to oil supply is a big factor in explaining the differences in retail gasoline prices across states, there would not be a long-run equilibrium relationship between gasoline price series in states with no refineries and states with refineries. This hypothesis is tested among southern states with and without oil refineries over the period 1983 through 2007 using dynamic correlation analysis and cointegration analysis. Dynamic correlation results showed similar trends in states with and with no oil refineries in the short-run. Cointegration results found group average price series for states with no refineries to be moving together with individual price series for states with oil refineries in the long-run. Thus, the overall finding is evidence of a long-run equilibrium over the studied period, implying that proximity to supply as measured by the presence of an oil refinery in a state does not significantly explain the differences in gasoline prices across states in the southern U.S. over the studied period.

\section{References:}

Alexander, C. \& Wyeth, J.. (1994). Cointegration and market integration: An application to the Indonesian rice market. Journal of Development Studies, 30, 303-328. 
Asche, F., Bremnes, H. \& Wessells, C. R.. (1999). Product aggregation, market integration, and relationships between prices: An application to world salmon markets. American Journal of Agricultural Economics, 81, 568-581.

Bentzen, J.. (2003). An empirical analysis of gasoline price convergence for 20 OECD countries. Working paper 03-19, Department of Economics, Aarhus School of Business.

Bernard, A. B. \& Durlauf, S. N.. (1995). Convergence in International output. Journal of Applied Econometrics, 10, 97-108.

Bukenya, J. O. \& Labys, W. C.. (2005). Price convergence on world commodity markets: Fact or fiction. International Regional Science Review, 28, 302-329.

Caner, M. \& Hansen, B. E.. (2001). Threshold autoregression with a unit root. Econometrica, 69, 1555-1596.

Davidson, R. \& MacKinnon, J. G.. (1993). Estimation and inference in econometrics. New York: Oxford University Press.

Dibooglu, S. \& Aleisa, E.. (2004). Oil prices, terms of trade shocks, and macroeconomics fluctuations in Saudi Arabia. Contemporary Economics Policy, 22(1), 50-62.

Dickey, D. A. \& Fuller, W. A.. (1979). Distribution of estimates for autoregressive time series with unit root. Journal of the American Statistical Association, 74, 427-31.

Dickey, D. A. \& Fuller, W. A.. (1981). Likelihood ratio statistics for autoregressive time series with a unit root. Econometrica, 49, 1057-1072.

EIA. (2007). Energy information administration: Country analysis briefs. Saudi Arabia. Retrieved from http://www.eia.doe.gov/emeu/cabs/Saudi_Arabia/Background.html.

EIA. (2008). Energy information administration: International petroleum (oil) prices and crude oil import costs. Retrieved from http://www.eia. doe.gov/emeu/international/oilprice.html.

Fattouh, B.. (2008). The dynamics of crude oil price differentials. Centre for Financial and Management Studies, SOAS and Oxford Institute for Energy Studies. Manuscript.

Fuller,W. A.. (1976). Introduction to statistical time series. New York: JohnWiley \& Sons.

Goodwin, B. K.. (1992). Multivariate cointegration tests and the law of one price in international wheat markets. Review of Agricultural Economics, 14(1) 117-124.

Granger, C. W. J.. (1986). Developments in the study of cointegrated economic variables. Oxford Bulletin of Economics and Statistics, 48, 213-228.

Gülen, S. G.. (1996). Is OPEC a cartel? Evidence from cointegration and causality tests. Working papers in economics, Number 315, Economics Department, Boston College. Retrieved from http://escholarship.bc.edu/econ papers/315.

Gülen, S. G.. (1997). Regionalization in the world crude oil market. The Energy Journal, 18(2), 109-126.

Hansen, P. \& King, A.. (1996). The determinants of health care expenditure: A cointegration approach. Journal of Health Economics, $15,127-137$.

Kyrtsau, C. \& Labys, W. C.. (2005). Evidence for chaotic dependence between commodity prices and US inflation. Journal of Macroeconomics, 28(1), 256-266.

Labys, W. C.. (2000). Can world market volatility upset the U.S. economy? Economic Directions, Center for Economic and Policy Research, St Vincent College, Latrobe, PA..

McCoskey, S. K. \& Selden, T. M.. (1998). Health care expenditures and GDP: Panel data unit root test results. Journal of Health Economics, 17, 369-376.

Mork, K. A.. (1994). Business cycles and the oil market. Energy Journal, 15(special issue), 15-38.

Pirog, R.. (2004). The effects of oil shocks on the economy: A review of the empirical evidence. CRS Report for Congress. Congressional Research Service. The Library of Congress, Order Code RL31608.

Pirog, R.. (2005). World oil demand and its effect on oil prices. CRS Report for Congress. Congressional Research Service. The Library of Congress, Order Code RL32530.

Rogoff, K.. (2006). Oil and the global economy. Manuscript, Harvard University.

Stevens, P.. (2004). The future price of crude oil. Middle East Economic Survey, XLVII(37), Retrieved from http://www.mees.com/postedarticles/oped/a47n37d01.htm.

Weiner, R. J.. (1991). Is the world oil market “one great pool”? The Energy Journal, 12(3), 95-107.

Williams, J. L.. (2008). Oil price history and analysis. Retrieved from http://www.wtrg.com/prices.htm.

Zanias, G. P.. (1993). Testing for integration in European community agricultural product markets. Journal of Agricultural Economics, 44(3), 418-427.

(Edited by Ruby and Chris) 